\title{
Water and Radiation Use Efficiencies by Erythrina velutina and Enterolobium contortisiliquum Under Different Water Conditions
}

\author{
Yara Panta de Araújo ${ }^{1}$ \\ Luciana Sandra Bastos de Souza ${ }^{1}$ \\ Thieres George Freire da Silva ${ }^{1}$ (i) \\ Magna Soelma Beserra de Moura² ${ }^{2}$
}

\begin{abstract}
This study investigated the water and radiation use efficiencies by Erythrina velutina and Enterolobium contortisiliquum under four water regimes. The experiment was carried out in the municipality of Serra Talhada, PE, Brazil. The experimental design was completely randomized with a $2 \times 4$ factorial arrangement and three replications. The water regimes were imposed from water replenishments based on the reference evapotranspiration (25, 50, 75 and $100 \%$ ET0). Water and radiation use efficiencies were calculated to the 120 days of growth. E. velutina showed a greater accumulated dry biomass $\left(4.89 \mathrm{~g} \mathrm{pl}^{-1}\right)$ than E. contortisiliquum $\left(2.22 \mathrm{~g} \mathrm{pl}^{-1}\right)$. The $75 \%$ ET0 water regime can be adopted without damage to the growth of both species. E. velutina was more efficient in the conversion of water $\left(0.42 \mathrm{gl}^{-1}\right)$ and radiation in dry biomass $\left(0.028 \mathrm{~g} \mathrm{MJ}^{-1}\right)$, indicating high environmental resilience, which is important features to choose species more adequate for reforestation activities.
\end{abstract}

Keywords: Caatinga, radiation use efficiency, water use efficiency.

\section{INTRODUCTION}

Seasonally dry tropical forests (SDTF) have peculiar morphophysiological mechanisms that give them resilience to adverse environmental conditions and great importance in the terrestrial carbon balance (Aragão et al., 2019). However, studies on the morphophysiological aspects and establishment of SDTF species are scarce and incipient (Dexter et al., 2018). This information is essential for the understanding of their relationship with abiotic factors (Trovão et al., 2007).

In Brazil, the SDTF is represented by the Caatinga. Such forest encompasses the vegetation that covers the semi-arid region (Queiroz et al., 2019). The Caatinga has approximately $912,529 \mathrm{~km}^{2}$ (SILVA et al., 2017) and is subject to high radiation, high temperatures $\left(23-27^{\circ} \mathrm{C}\right)$ and low relative humidity $(60 \%)$, thus resulting in high atmospheric demand, which combined with the poor distribution of rainfall in space and

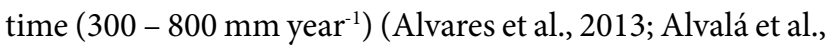
2019), implies a negative water balance (Moura et al., 2007; Alvalá et al., 2019), which limits the development of the plants.
The Caatinga is composed of species adapted to environmental stress conditions, with leaves converted into thorns, some with photosynthesizing stems and reduction of leaf area by deciduous to decrease transpiration (Silva et al., 2004). Despite all those facts, in the early stages of growth, when seedling survival is conditioned by seed germination capacity and root system deepening (Figueirôa et al., 2004), the occurrence of water deficit can be lethal.

Studies carried out during the early development of the species are extremely useful because of their susceptibility to variations in the environment over the establishment. The information generated is essential for the creation of more efficient strategies in the production of seedlings, the understanding of the maintenance of the forests, and can also serve as the basis for the execution of reforestation activities (Lenhard et al., 2010).

The tolerance of the species to the environment can be studied by the calculation of indicators of use efficiency of natural resources such as water and radiation. In the first case, the water use efficiency allows us to understand the

\footnotetext{
${ }^{1}$ Universidade Federal Rural de Pernambuco (UFRPE), Serra Talhada, PE, Brasil

${ }^{2}$ Empresa Brasileira de Pesquisa Agropecuária (EMBRAPA), Petrolina, PE, Brasil
} 
water conversion capacity in biomass (Geerts \& Raes, 2009; Silva et al., 2011); in the second case, the radiation use efficiency helps to understand the efficiency of the plants in absorbing and producing photoassimilates for the production of biomass (Battacharya, 2019). These two indicators can vary according to the leaf area index, height, age, and leaf arrangement of the plant (Battacharya, 2019).

Efficiencies in the use of water and radiation help to understand the plant responses to environmental stresses and selection of more adapted species, besides being key parameters in growth models, ecosystem productivity and among other applications (Silva et al., 2014; Teixeira et al., 2015).

Efficiencies of water and radiation use have been studied extensively for crops and are poorly exploited for native species (Souza et al., 2015). The species Enterolobium contortisiliquum (Vell.) Morong and Erythrina velutina Willd. belong to the Fabaceae family (Lima, 2019; Morim, 2019), which has an extensive occurrence in the Caatinga domain. The studied species present ecological and economic importance, and fast growth, desirable characteristics for the use in reforestation programs in degraded areas (Melo et al., 2008). Additionally, knowledge of how they use natural resources such as radiation and water can be useful for the preservation of ecosystem services in the Caatinga. This study investigated the water and radiation uses efficiencies by Enterolobium contortisiliquum and Erythrina velutina submitted to different water availability conditions.

\section{METHODOLOGY}

The experiment was conducted in a nursery covered with commercial shadow cloth located in the Academic Unit of
Serra Talhada (75'ㅇ; $38^{\circ} 18^{\prime} \mathrm{O} ; 499 \mathrm{~m}$ ) of the Universidade Federal Rural de Pernambuco, municipality of Serra Talhada, state of Pernambuco. The experimental period was from June 72018 to October 5 2018. The climate of the region is semi-arid according to the classification of Köppen, characterized by average temperatures around $26^{\circ} \mathrm{C}$, relative humidity of $63 \%$ and intense solar radiation incidence (Pereira et al., 2015). The annual rainfall is $642 \mathrm{~mm}_{\text {year }}{ }^{-1}$, most of it occurring in four months (Pereira et al., 2015; Alvalá et al., 2019).

Atmospheric conditions were monitored using a meteorological station owned by the National Institute of Meteorology (INMET - http://www.inmet.gov.br), located $300 \mathrm{~m}$ from the experiment area over the experimental period. Average hourly data were obtained from the following meteorological elements: average air temperature $\left(\mathrm{T},{ }^{\circ} \mathrm{C}\right)$, air relative humidity $(\mathrm{RH}, \%)$ (Figure 1a), rainfall $\left(\mathrm{mm} \mathrm{day}^{-1}\right)$, and solar radiation $\left(\mathrm{MJ} \mathrm{m}^{-2} \mathrm{~d}^{-1}\right)$ (Figure $1 \mathrm{~b}$ ). During the experiment period there was no need control of the rainfall due to low occurred events and the protection promoted by nursery (Figure 1b).

This information was converted into daily averages over time. In addition, the experiment was conducted when average temperatures were around $25.5^{\circ} \mathrm{C}$, with minimum and maximum values of $22.5^{\circ} \mathrm{C}$ and $29.0^{\circ} \mathrm{C}$, respectively. Air relative humidity ranged from $35 \%$ to $70 \%$, with an average of $51 \%$. Also, a high solar radiation index (mean of $23.7 \mathrm{MJ} \mathrm{m}^{2}$ day) and low rainfall volumes were observed, with a total accumulated of $12 \mathrm{~mm}$ during the experimental period.
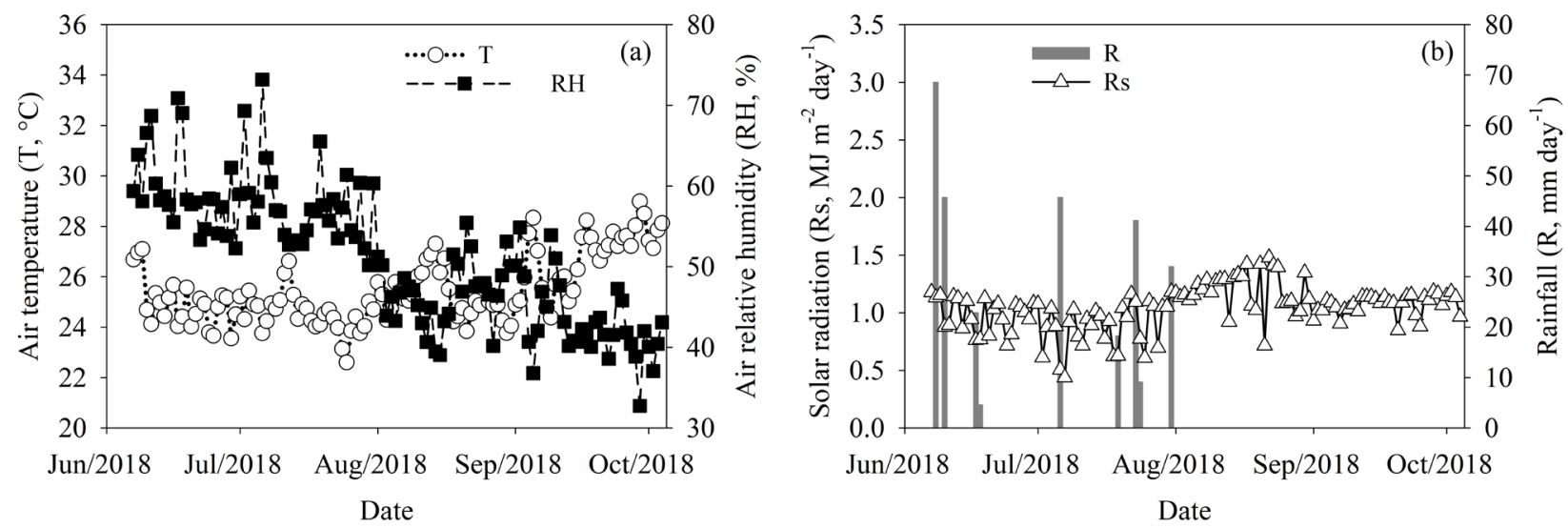

Figure 1. Temperature and air relative humidity (a), solar radiation and daily rainfall (b) in the municipality of Serra Talhada, state of Pernambuco over the experimental period. 
The soil used in the experiment had its physical characteristics determined using samples were randomly obtained at the 0-20 and 20-40 cm depths (Table 1).

Table 1. Physical attributes of the soil used in different depths $(0-20$ and $20-40 \mathrm{~cm})$, in the municipality of Serra Talhada, state of Pernambuco.

\begin{tabular}{ccccccc|} 
Depths & $\rho s$ & $\rho p$ & $\Phi t$ & Total sand & Silt & Clay \\
\hline $\mathbf{c m}$ & \multicolumn{2}{c}{$\mathbf{k g ~ d m}^{-3}$} & $\%$ & & $\begin{array}{c}\mathbf{g} \\
\mathbf{k g}^{-1}\end{array}$ & \\
\hline $0-20$ & 1.30 & 2.5 & 48.3 & 815.2 & 128.4 & 56.4 \\
$20-40$ & 1.32 & 2.5 & 47.9 & 828.5 & 134.3 & 37.1 \\
\hline
\end{tabular}

$\rho s=$ Soil density; $\rho p=$ Particle density; $\varphi \mathrm{t}=$ Total porosity of the soil.

Pots with $21.5 \mathrm{~cm}$ in diameter (5 L) were used (Figure 2). They were filled with soil sieved in $2 \mathrm{~mm}$ mesh and $200 \mathrm{~mL}$ worm humus. Subsequently, the pots were placed in the field capacity using a volume of water equivalent to $1250 \mathrm{ml}$ in each pot.

The experiment was conducted in a completely randomized design, in a $2 \times 4$ factorial arrangement, with two species and four water regimes, in three replicates. The species E. contortisiliquum and E. velutina were used. Their seeds were initially submitted to scarification with wood sandpaper to break dormancy and seeded in the pots. The water regimes were imposed from the water replenishment based on the fractionation of the reference evapotranspiration (ET0): $25 \%(7.4 \mathrm{~L}) ; 50 \%(10.3 \mathrm{~L})$, $75 \%(13.3 \mathrm{~L})$ and $100 \%(16.3 \mathrm{~L})$. In the first 34 days after sowing (DAS), daily replenishment was also executed for all plants based on $100 \%$ ET0, calculated using the Penman-Monteith equation (Equation 1) standardized by FAO56 (Allen et al., 1998), using the meteorological information obtained during the experiment:

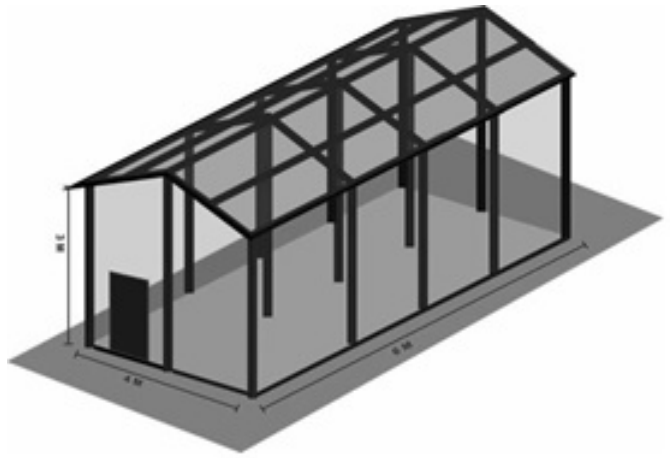

(a)

$$
\mathrm{ET} 0=\frac{0.408 \Delta(\mathrm{Rn}-\mathrm{G})+\gamma\left(\frac{900}{\mathrm{t}+273}\right) \mathrm{u}_{2}\left(\mathrm{e}_{\mathrm{s}}-\mathrm{e}_{\mathrm{a}}\right)}{\Delta+\gamma\left(\begin{array}{c}
1+0 . \\
34 \mathrm{u}_{2}
\end{array}\right)}
$$

where: ET0 - reference evapotranspiration $\left(\mathrm{mm} \mathrm{d}^{-1}\right) ; \Delta$ - slope of the saturation water vapor pressure curve $\left(\mathrm{kPa}^{\circ} \mathrm{C}^{-1}\right) ; \mathrm{Rn}$ - surface radiation balance $\left(\mathrm{MJ} \mathrm{m}^{-2} \mathrm{~d}^{-1}\right)$; $\mathrm{G}$ - sensible heat flux density in the soil $\left(\mathrm{MJ} \mathrm{m}^{-2} \mathrm{~d}^{-1}\right) ; \mathrm{t}$ - daily average air temperature $\left({ }^{\circ} \mathrm{C}\right)$; $\mathrm{u}_{2}$ - wind speed in $2 \mathrm{~m}$ height $\left(\mathrm{m} \mathrm{s}^{-1}\right)$; es-water vapor saturation pressure $(\mathrm{kPa})$; ea - partial pressure of water vapor $(\mathrm{kPa})$ and $\gamma$ - psychometric constant $\left(\mathrm{kPa}^{\circ} \mathrm{C}^{-1}\right)$.

During the experimental period, a campaign was made to obtain information on the biomass of the seedlings. In this case, three individuals of each treatment were obtained to the end of the experiment on October 5 2018. Those individuals had their organs separated and allocated in Kraft paper bags. These were properly identified and taken to a forced-air circulation oven at $60^{\circ} \mathrm{C}$ for about $72 \mathrm{~h}$. The samples were then weighed using a 0.001-g scale (Model MARK 210A, Bel Engineering, Monza-MI, Italy) to obtain data on the root dry biomass (RDB, $\mathrm{g} \mathrm{pl}^{-1}$ ), dry leaf biomass (DLB, $\mathrm{g} \mathrm{pl}^{-1}$ ), stem dry biomass $\left(\mathrm{SDB}, \mathrm{g} \mathrm{pl}^{-1}\right)$, aerial part dry biomass $(\mathrm{APDB}=\mathrm{DLB}+\mathrm{SDB}$, $\left.\mathrm{g} \mathrm{pl}^{-1}\right)$, total dry biomass $\left(\mathrm{TSD}=\mathrm{RDB}+\mathrm{DLB}+\mathrm{SDB}, \mathrm{g} \mathrm{pl}^{-1}\right)$ and $\mathrm{DLB} / \mathrm{TDB}$ and $\mathrm{RDB} / \mathrm{TDB}$ partitions.

Water use efficiency was obtained by the ratio between total dry biomass and total volume of water applied (Geerts \& Raes, 2009; Silva et al., 2011) (Equation 2).

$$
\mathrm{WUE}=\frac{\mathrm{TDB}}{\mathrm{V}}
$$

where: WUE is the water use efficiency $\left(\mathrm{gl}^{-1}\right), \mathrm{TDB}$ is the total dry biomass $\left(\mathrm{g} \mathrm{pl}^{-1}\right)$, and $\mathrm{V}$ is the total volume of water applied $\left(\mathrm{l}^{-1}\right)$.

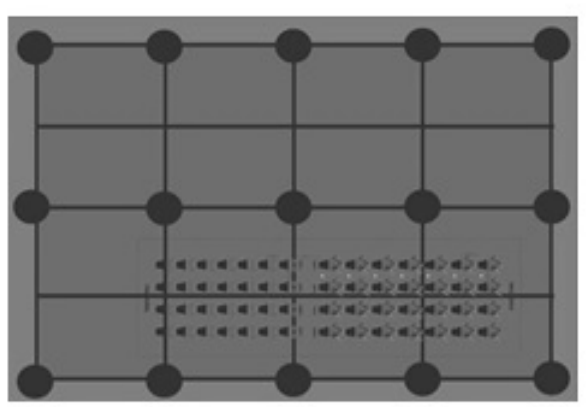

(b)

Figure 2. Diagrammatic representation of the nursery (a), construction drawing with plant arrangement on the sketch (b), in the municipality of Serra Talhada, state of Pernambuco (Elaborated by Nogueira, F. B.). 
Over the experiment, photosynthetically active radiation (PAR) was measured at different positions inside $\left(\mathrm{PAR}_{\text {internal }}\right)$ and outside $\left(\mathrm{PAR}_{\text {external }}\right)$ of the nursery. Four readings were conducted, one above $\left(\mathrm{PAR}_{\mathrm{AP}}\right)$ and the other three readings at different positions below $\left(\mathrm{PAR}_{\mathrm{BP}}\right)$ the plant. For this purpose, the AccuPAR (Decagon Devices, Inc., Pullman, Washington, USA) ceptometer was used and the value of the photosynthetically active radiation was obtained through the average of the readings. Measurements were performed between 11 a.m. and 2 p.m., with intervals of 8 days, totaling 12 campaigns. This information was used to determine the intercepted photosynthetically active radiation (PARp), using the equations described by Gower (1999) (Equation 3).

$$
\mathrm{PAR}_{\mathrm{p}}=1-\frac{\mathrm{PAR}_{\mathrm{Ap}}}{\mathrm{PAR}_{\mathrm{BP}}}
$$

Where $\mathrm{PAR}_{\mathrm{Ap}}=$ photosynthetically active radiation above the plant $\left(\mathrm{MJ} \mathrm{m}^{-2} \mathrm{~d}^{-1}\right), \mathrm{PAR}_{\mathrm{Bp}}=$ photosynthetically active radiation incident below the plant $\left(\mathrm{MJ} \mathrm{m}^{-2} \mathrm{~d}^{-1}\right)$.

Data on PARp were used to adjust sigmoid equations in order to estimate their values for every day over the experiment as a function of DAS.

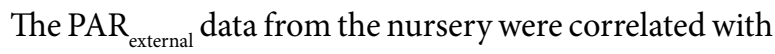
the global solar radiation data of INMET meteorological station, as reported by Caron et al. (2014), resulting in the following relation:

$$
\mathrm{PAR}_{\text {external }}=0.48 \times \mathrm{Rg}
$$

where: $\mathrm{Rg}=$ global solar radiation $\left(\mathrm{MJ} \cdot \mathrm{m}^{-2} \cdot \mathrm{d}^{-1}\right)$.
Radiation use efficiency (RUE, $\mathrm{g} \mathrm{MJ}^{-1}$ ) was obtained through the ratio between cumulative intercepted radiation (CIPAR) and total dry biomass during the experiment in each treatment using equation 5 . The use of shadow cloth promoted a $45 \%$ attenuation of the $\mathrm{PAR}_{\text {external }}$. Like, this the $\mathrm{PAR}_{\text {external }}$ values were used for the calculation of the PAR $\mathrm{internal}$. The CIPAR for each species throughout the experiment was derived from the product between $\mathrm{PAR}_{\text {internal }}$ and $\mathrm{PAR}_{\mathrm{p}}$.

$$
\mathrm{RUE}=\frac{\mathrm{TDB}}{\mathrm{CIPAR}}
$$

where: TDB is the total dry biomass $\left(\mathrm{g} \mathrm{pl}^{-1}\right)$ and CIPAR is the cumulative intercepted radiation over the period $\left(\mathrm{MJ} \mathrm{m}^{-2} \mathrm{day}^{1}\right)$.

The experimental data were submitted to the normality and homoscedasticity test, analysis of variance, and the means were compared by the test of Tukey at the $5 \%$ probability level. Regression tests were performed whenever it was needed.

\section{RESULTS AND DISCUSSION}

Significant differences were found for the species and, or, water regime factors at the $5 \%$ probability level for the following parameters: dry leaf biomass (DLB), stem dry biomass (SDB), total dry biomass (TDB), dry leaf biomass/total dry biomass ratio (DLB/TDB), stem dry biomass /total dry biomass ratio (SDB/TDB), total aerial part dry biomass (APDB) and water use efficiency (WUE). No interaction effect was found between the species and the water regime $(p>0.05)$ (Table 2). Therefore, regardless of the water regime, the species Erythrina velutina presented higher biomass accumulation in relation to Enterolobium contortisiliquum. In turn, the $75 \%$ ET0 allowed for greater growth independent of the species.

Table 2. Analysis of variance (ANOVA) for dry leaf biomass (DLB), stem dry biomass (SDB), root dry biomass (RDB), aerial part total dry biomass (APDB), dry leaf biomass - total dry biomass ratio (DLB/TDB), stem dry biomass - total dry biomass ration (SDB/TDB), root dry biomass - total dry biomass (RDB/TDB) and water use efficiency (WUE) in relation to the effects of the species and water factors. SS: sum of squares; MS: mean square; F: statistic of test F and P represents the significance.

$\begin{array}{cccccc}\begin{array}{c}\text { Source of } \\ \text { variation }\end{array} & \text { Variables } & \text { SS } & \text { MS } & \text { F } & \text { P } \\ & \text { DLB } & 2.13 & 2.13 & 16.49 & 0.000909^{* *} \\ & \text { SDB } & 56.25 & 56.25 & 145.15 & 0.000000^{* *} \\ \text { RDB } & 0.25 & 0.25 & 2.99 & 0.103253^{\text {ns }} \\ & \text { APDB } & 36.48 & 36.48 & 72.07 & 0.000000^{* *} \\ & \text { TDB } & 42.80 & 42.80 & 83.15 & 0.000000^{* *} \\ & \text { DLB/TDB } & 0.96 & 0.96 & 148.27 & 0.000000^{* *} \\ & \text { SDB/TDB } & 1.32 & 1.33 & 339.05 & 0.000000^{* *} \\ & \text { RDB/TDB } & 0.03 & 0.030 & 3.93 & 0.064485^{\text {ns }} \\ & \text { WUE } & 0.34 & 0.334 & 112.96 & 0.000000^{* *}\end{array}$


Table 2. Continued...

\begin{tabular}{|c|c|c|c|c|c|}
\hline $\begin{array}{l}\text { Source of } \\
\text { variation }\end{array}$ & Variables & SS & MS & $\mathbf{F}$ & $\mathbf{P}$ \\
\hline \multirow{9}{*}{ Blade } & DLB & 2.17 & 0.72 & 5.60 & $0.008063^{* *}$ \\
\hline & SDB & 7.74 & 2.8 & 6.66 & $0.003975^{* *}$ \\
\hline & RDB & 1.35 & 0.45 & 5.32 & $0.009735^{\mathrm{ns}}$ \\
\hline & APDB & 17.35 & 5.78 & 11.41 & $0.000299^{* *}$ \\
\hline & TDB & 28.23 & 9.41 & 18.28 & $0.000020^{* *}$ \\
\hline & DLB/TDB & 28.23 & 9.41 & 18.28 & $0.000020^{* *}$ \\
\hline & BSC/TDB & 0.02 & 0.01 & 2.00 & $0.154364^{\mathrm{ns}}$ \\
\hline & BSR/TDB & 0.01 & 0.004 & 0.60 & $0.0622404^{\mathrm{ns}}$ \\
\hline & WUE & 0.03 & 0.009 & 3.09 & $0.056703^{\mathrm{ns}}$ \\
\hline \multirow{9}{*}{ Blade X Species } & DLB & 0.24 & 0.78 & 0.60 & $0.622544^{\mathrm{ns}}$ \\
\hline & SDB & 2.85 & 0.95 & 2.45 & $0.100892^{\mathrm{ns}}$ \\
\hline & RDB & 0.90 & 0.30 & 3.57 & $0.037761^{\mathrm{ns}}$ \\
\hline & APDB & 2.61 & 2.87 & 1.72 & $0.202797^{\mathrm{ns}}$ \\
\hline & TDB & 1.42 & 0.47 & 0.92 & $0.452897^{\mathrm{ns}}$ \\
\hline & DLB/TDB & 0.47 & 0.01 & 2.43 & $0.102888^{\mathrm{ns}}$ \\
\hline & SDB/TDB & 0.01 & 0.004 & 1.19 & $0.343176^{\mathrm{ns}}$ \\
\hline & RDB/TDB & 0.07 & 0.024 & 3.24 & $0.050121^{\mathrm{ns}}$ \\
\hline & WUE & 0.01 & 0.003 & 1.26 & $0.320732^{\mathrm{ns}}$ \\
\hline
\end{tabular}

${ }^{*}$ significance at $5 \%,{ }^{\mathrm{ns}}$ not significant.

The effects of the species (Figure 3a-f) demonstrated that E. contortisiliquum had $57 \%$ higher dry leaf biomass (DLB) production than E. velutina (Figure 3a). This behavior may be directly associated with the leaf morphology of each species, as E. velutina displays simple leaves (and in smaller numbers), while E. contortisiliquum exhibits compound leaves with faster development. According to Oliveira et al. (2007), the leaves are the structures responsible for the production of most of the carbohydrates necessary for the growth of the plant. In this situation, the mass gain of the plant depends on its capacity to convert natural resources into biomass.

The dry stem biomass (DSB) showed an inverse behavior to that observed for DLB between the species. It can be seen that E. velutina displayed $83 \%$ more SDB than E. contortisiliquum (Figure $3 \mathrm{~b}$ ). At this stage of growth, the stem of E. velutina showed to be more robust, therefore demonstrating that this species invested more in a support structure when compared to E. contortisiliquum (DSB/TDB, Figure 3e). Santos et al. (2013) mention that the increment in the DSB/TDB partition can occur due to the contribution of defense structures of the plant, as is the case of aculeus. As a consequence, a more significant investment was observed in the aerial part biomass (APDB) and total dry biomass (TDB) for E. velutina in relation to E. contortisiliquum (Figures 3c-d, respectively). E. velutina showed about twice the capacity of TDB accumulation when compared to E. contortisiliquum (Figure 3d). Concerning the accumulation of dry biomass by the roots $(\mathrm{RDB})$, no differences were observed between the species. Different results were observed by Barbosa et al. (2013) analyzing the initial growth of Caatinga species. They noticed that E. contortisiliquum exhibited higher RDB when compared to E. velutina, Piptadenia stipulacea, and Anadenanthera macrocarpa.

The DLB, SDB, APDB, TDB and the DLB/TDB partition increased as water regime was incremented, therefore, reaching higher magnitudes in the water replenishment of $100 \%$ ET0 (Figure 4a-e). However, except for TDB (Figure 4d) no statistical difference was found between the conditions of $50 \%$ ET0, $75 \%$ ET0 and 100\% ET0 for most variables; that is, the smallest accumulated values of biomass were verified in the $25 \%$ ET0 water regime. But accumulated values of biomass in the $25 \%$ ET0 water regime did not differ from the 50\% ET0 water regime. Like this, the $75 \%$ ET0 water regime can be adopted without damage to the growth of both species.

The 25\% ET0 blade reduces the APDB accumulation by $59 \%$ when compared to the $100 \%$ ET0 water regime (Figure 4c). Santiago et al. (2001) indicate that plants under water stress establish strategies to reduce the loss of water to the atmosphere. Among those mechanisms, the stomatal closure and leaf wilting can be mentioned. They affect photosynthesis, therefore directly affecting plant growth. When analyzing the growth of Hymenaea courbaril seedlings, Nascimento et al. (2005) observed that the reduction of soil water availability to levels equivalent to $25 \%$ of the field capacity (FC) decreases the dry mass of leaves, stem, and total of the plant by $77 \%$, $71 \%$, and $70 \%$, respectively 

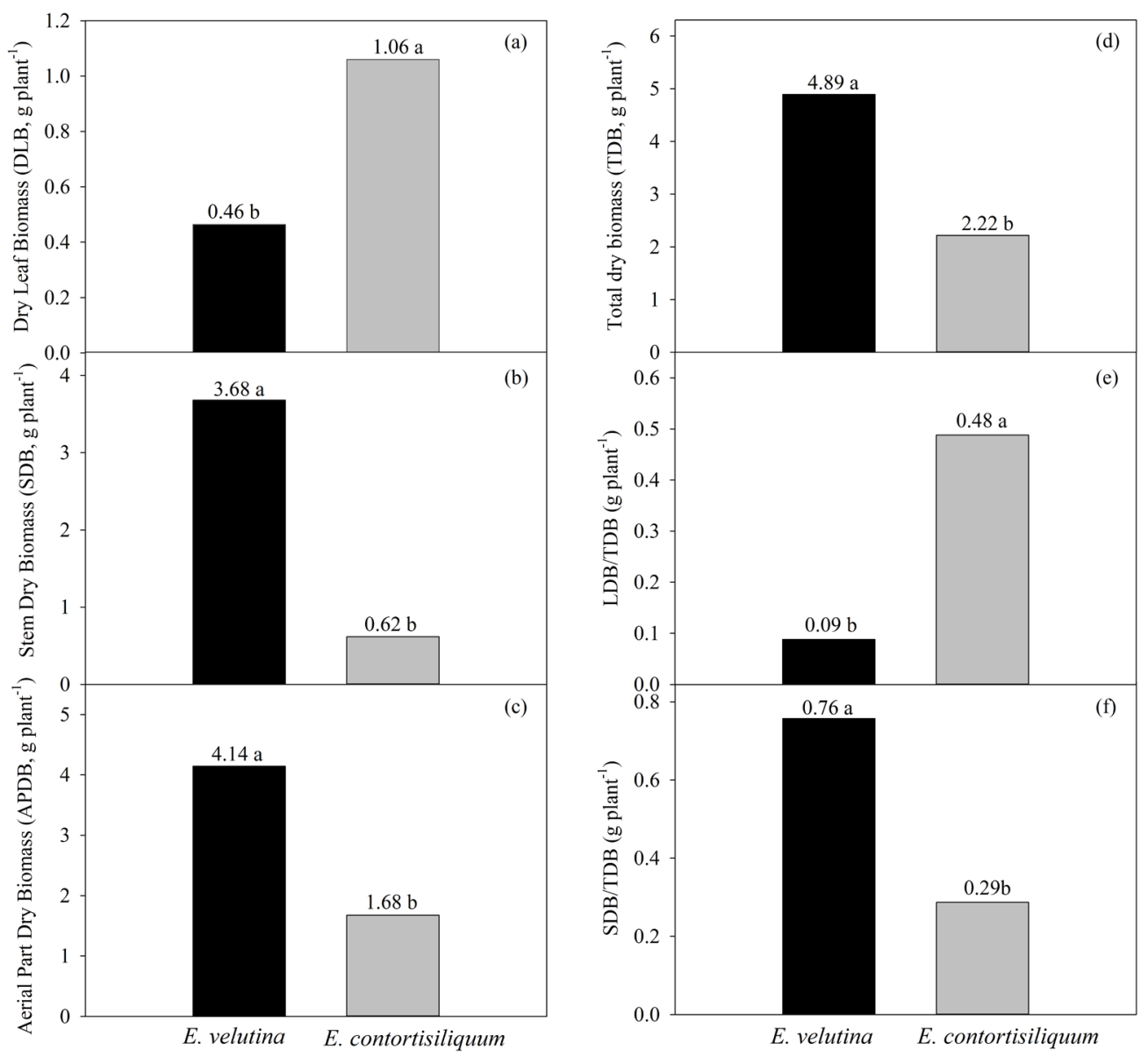

Figure 3. Dry leaf biomass - DLB (a), stem dry biomass - SDB (b), aerial part dry biomass (c), total dry biomass - TDB (d), dry leaf biomass/total dry biomass (DLB/TDB) (e) and stem dry biomass/total dry biomass (SDB/TDB) (f) for Erythrina velutina and Enterolobium contortisiliquum, regardless of water regime, in the municipality of Serra Talhada, state of Pernambuco.

The TDB in the $50 \%$ ET0 water regime presented an engagement to the accumulation of the biomass by $26 \%$ in relation to $100 \%$ ET0 (Figure $4 \mathrm{~d}$ ) while this reduction was $60 \%$ in the $25 \%$ ET0 water regime. A smaller contribution of the roots to the TDB occurred in both cases when compared to APDB. In spite of this, E. contortisiliquum invested more in the root system (25\% TDB) than E. velutina (19\% TDB). Santiago et al. (2001) performed a work using Mimosa caesalpiniifolia grown in water stress relative to field capacity percentages (FC) of $25 \%$ FC severe stress and 50\% FC - moderate stress. These authors observed that the increase in stress severity results in significant reductions in plant growth.

The species E. contortisiliquum and E. velutina showed significant differences in the water use efficiency; however, they were not affected by the water regimes, therefore, showing that these species exhibit high resilience in the early stages, with high capacity of water use. E. velutina was more efficient in the conversion of water to dry matter over the analyzed period, which can guarantee the maintenance of this species in the environment for a longer period of time. The plants that present greater efficiency of water use are able to show better development and establishment in places with low water availability (Pimentel, 2004). Souza (2014) studied the water use efficiency (WUE) based on photosynthesis and transpiration $(\mathrm{P} / \mathrm{T})$ in adults of five species and found that a slight increase in water deficit resulted in significant increases in the WUE. Similar results were observed by Gulías et al. (2002) for species native to the Mediterranean.

The greater WUE showed by E. velutina may also be associated with its ability to convert radiation into biomass (Figures $5 \mathrm{a}$ ). The ability of the plant to absorb radiation is a reflection of its leaf area and distribution geometry (Plénet et al., 2000). In this case, the leaf arrangement of E. velutina, with simple leaves and inserted perpendicularly to the stem, allowed greater interception of the photosynthetically active radiation. The 
presence of leaflets in E. contortisiliquum promotes greater transmittance of the radiation, which results in a reduction of $47 \%$ of the RUE in relation to $E$. velutina. However, intrinsic physiological and anatomical mechanisms of both species (i.e. photosynthetic rate, stomatal conductance, and stomata density), which were not measured here, may also have contributed to these results, since they modify the capacity of biomass accumulation by plants.

The low water regime reduces WUE of both species (Figure 5b). The occurrence of severe water deficit induced the plants to adjust the morphology such as leaf senescence to overcome environmental conditions (Figure 4a). According to Matos et al. (2018), in a study using Tectona grandis species, this behavior is typical of native species as an alternative for survival in the environment. The leaf reduction decreased the transpiring surface but did not compromise the WUE as it was not affected by the water regimes. The effect of water stress on the WUE was completely tied to DLB, so that the smaller the applied water depth, the lower the DLB, and the smaller the magnitude of the WUE.
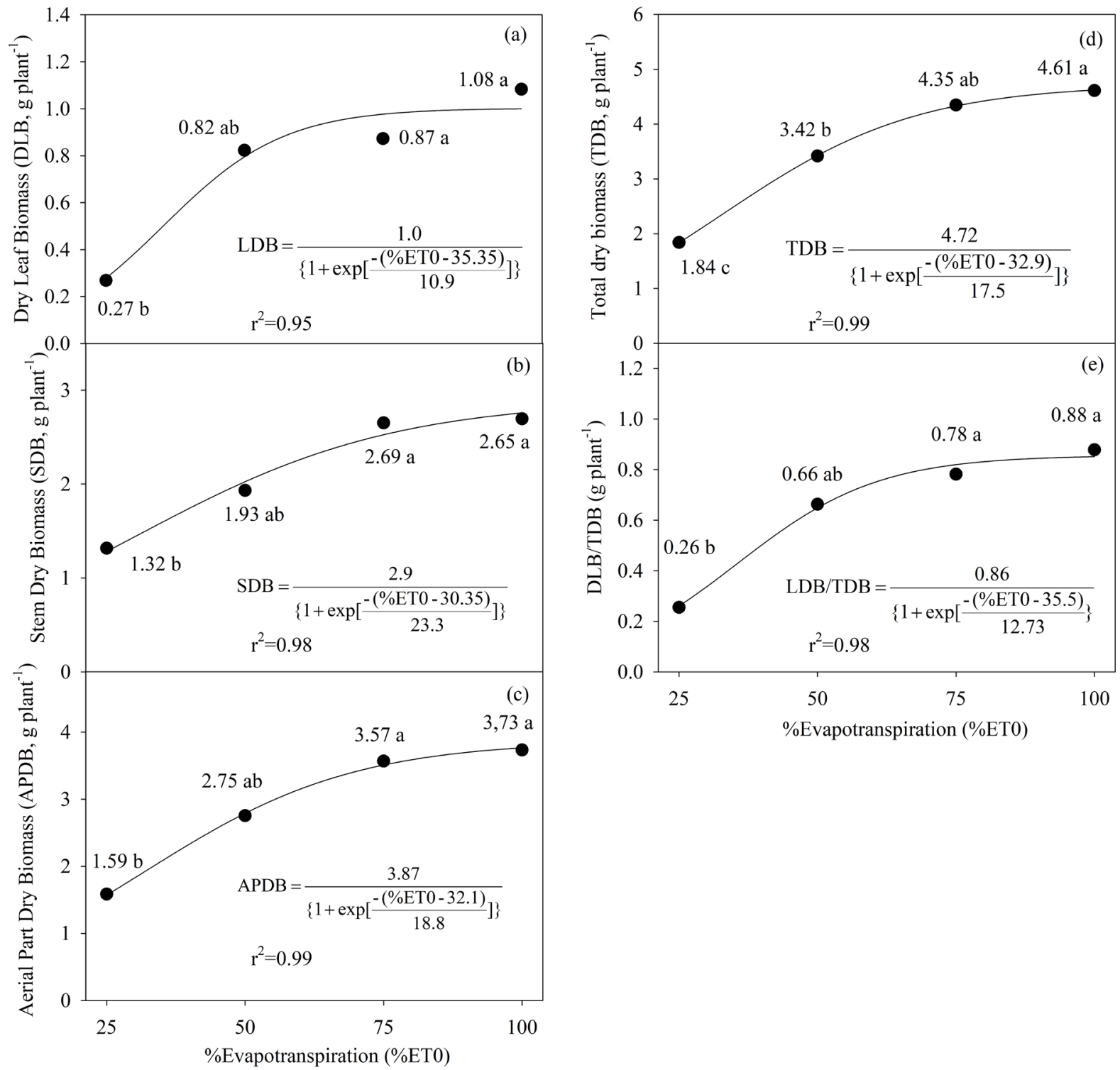

Figure 4. Dry leaf biomass - DLB (a), stem dry biomass - SDB (b), aerial part dry biomass - APDB (c), total dry biomass - TDB (d), dry leaf biomass/total dry biomass (e) according to the water regime (\%ET0) for Erythrina velutina e Enterolobium contortisiliquum, regardless of species, in the municipality of Serra Talhada, state of Pernambuco. 

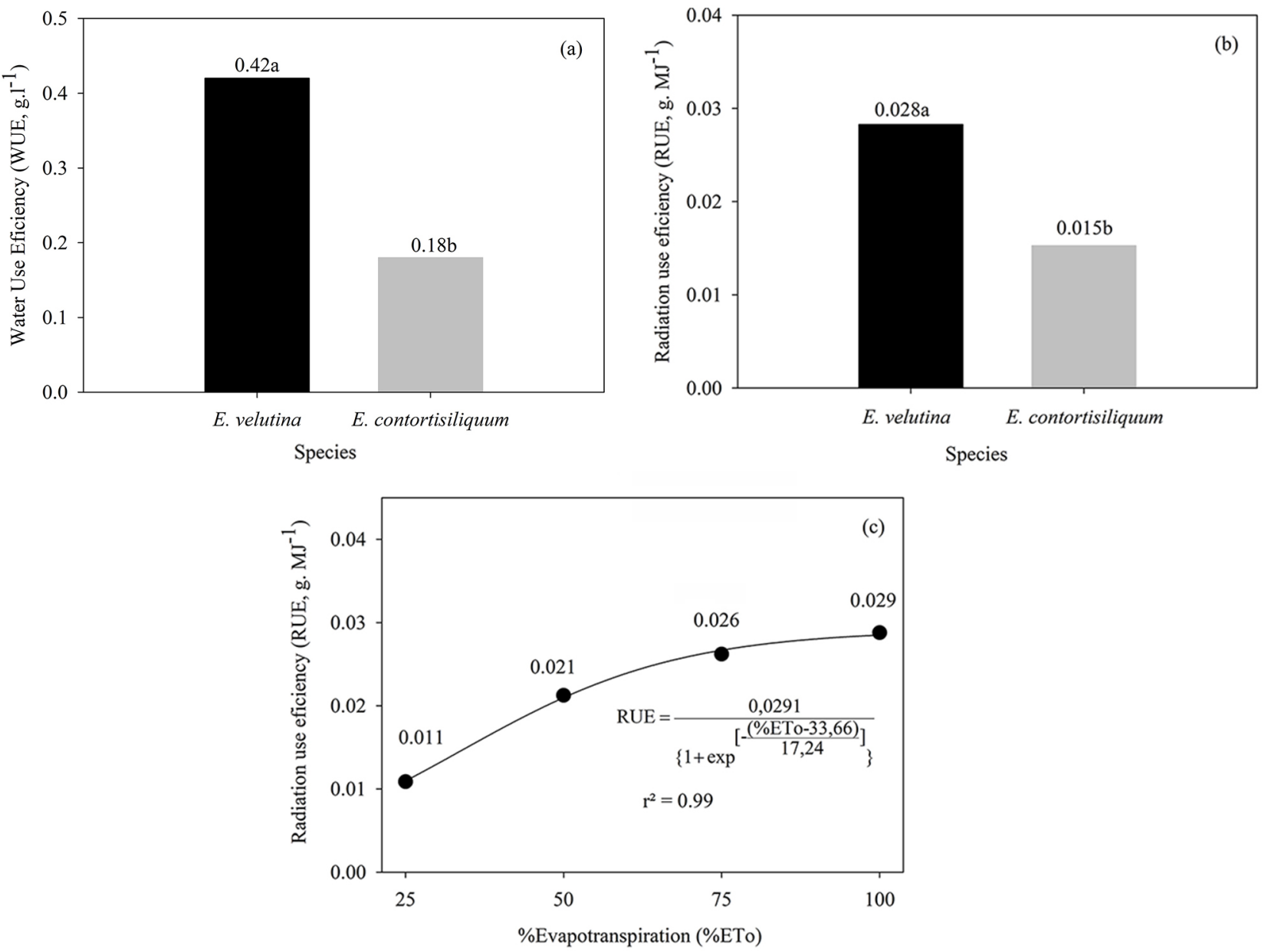

Figure 5. Water and radiation use efficiencies in relation to Erythrina velutina and Enterolobium contortisiliquum (A and B), regardless of water regime, and radiation use efficiency for different water regime $(\mathrm{C})$, regardless of species, in the municipality of Serra Talhada, state of Pernambuco.

\section{CONCLUSIONS}

In the first 120 days of growth, regardless of water regime, E. velutina showed a greater accumulated dry biomass $\left(4.89 \mathrm{~g} \mathrm{pl}^{-1}\right)$ than E. contortisiliquum $\left(2.22 \mathrm{~g} \mathrm{pl}^{-1}\right)$. The $75 \%$ ET0 water regime can be adopted without damage to the growth of both species. E. velutina was more efficient in the conversion of water $\left(0.42 \mathrm{gl}^{-1}\right)$ and radiation in dry biomass $\left(0.028 \mathrm{~g} \mathrm{MJ}^{-1}\right)$, indicating high environmental resilience, which is important features to choose species more adequate for reforestation activities.

\section{SUBMISSION STATUS}

Received: 18 Jun. 2019

Accepted: 08 Jun. 2020

Associate editor: Marcel Carvalho Abreu (1)

\section{CORRESPONDENCE TO}

\section{Thieres George Freire da Silva}

Universidade Federal Rural de Pernambuco (UFRPE), Avenida Gregório Ferraz Nogueira, S/N, Bairro José Tomé de Souza Ramos, CEP 56.909-535, Serra Talhada, PE, Brasil.

E-mail: thieres_freire@yahoo.com.br

\section{REFERENCES}

Allen RG, Pereira LS, Raes D, Smith M. Crop evapotranspiration: guidelines for computing crop water requirements. Rome: FAO, 1998.

Alvares CA, Stape, J L, Sentelhas, PC, Gonçalves JLM, Sparovek G. Köppen's climate classification map for Brazil. Meteorologische Zeitschrift 2013; 22 (6): 711-728.

Aragão, JRV, Groenendijk P, Lisi CS. Dendrochronological potential of four neotropical dry-forest tree species: Climate-growth correlations in northeast Brazil. Dendrochronologia 2019;53: 5-16. 
Alvalá RCS, Cunha APMA, Brito SSB, Seluchi ME, Marengo JA, Moraes OLL, Carvalho MA. Drought monitoring in the Brazilian Semiarid region. Anais da Academia Brasileira de Ciência 2019; 91 (1): 1-15.

Barbosa ML, Silva TGF, Silva AC, Almeida MG, Lima, ALA, Souza CAA. Crescimento Inicial de Espécies Ocorrentes no Semiárido Brasileiro: Biomassa, Biometria e Análise Morfogênica. Revista Brasileira de Geografia Física 2013; 6 (3): 522-539.

Battacharya, A. Chapter 2- Radiation-Use Efficiency Under Different Climatic Conditions. In: Changing Climate and Resource Use Efficiency in Plants. 1ed. Índia: Academic Press, 2019.

Caron BO, Schmidt D, Manfron PA, Behling A, Eloy E, Busanello C. Eficiência do uso da radiação solar por plantas Ilex paraguariensis A. St. Hil. cultivadas sob sombreamento e a pleno sol. Ciência Florestal 2014; 24 (2): 1-9.

Dexter KG, Pennington RT, Oliveira-Filho AT, Bueno ML, Miranda PLS, Neves DM. Inserting tropical dry forests into the discussion on biome transitions in the tropics. Frontiers in Ecology and Evolution 2018; 6 (6): 1-7.

Figueirôa JM, Barbosa DCA, Simabukuro EA. Crescimento de plantas jovens de Myracroduon urundeuva Allemão (Anacardiaceae) sob diferentes regimes hídricos. Acta Botanica Brasilica 2004; 18 (3): 573-580.

Geerts S, Raes D. Deficit irrigation as an on-farm strategy to maximize crop water productivity in dry areas. Agricultural Water Management 2009; 96 (9): 1275-1284.

Gower ST, Kucharik CJ, Norman JC. Direct and indirect estimation of leaf area index, $\mathrm{f}$ PAR, and net primary production of terrestrial ecosystems. Remote Sensing of Environment 1999; 70 (1) 29-51.

Gulías J, Flexas J, Abadía A, Medrano, H. Photosynthetic responses to water deficit in six Mediterranean sclerophyll species: possible factors explaining the declining distribution of Rhamnus ludovici-salvatoris, an endemic Balearic species. Tree Physiology 2002; 22 (10): 687-697.

Lenhard RN, Scalon SPQ, Novelino JO. Crescimento inicial de mudas de pau-ferro (Caesalpinea férrea MART. Ex Tul. Var. leiostachya Benth.) sob diferentes regimes hídricos. Ciência Agrotecnologia 2010; 34 (4): 870-877.

Lima HC, Martins MV. Erythrina in Lista de Espécies da Flora do Brasil. Jardim Botânico do Rio de Janeiro. [cited 2019 jun. 7]. Available from: <http://floradobrasil.jbrj.gov.br/jabot/floradobrasil/FB29679>.

Matos FS, Freitas IAS, Souza BR, Lopes VA, Rosa VR. Crescimento de plantas de Tectona grandis sob restrição hídrica. Revista Agrarian 2018;11 (39):14-21.

Melo RR, Cunha MCL, Rodolfo Junior F, Stangerlin DM. Crescimento inicial de mudas de Enterolobium contortisiliquum (Vell.) Morong. sob diferentes níveis de luminosidade. Revista Brasileira de Ciências Agrárias 2008; 3 (2), 138-144.

Morim MP. Enterolobium in Lista de Espécies da Flora do Brasil. Jardim Botânico do Rio de Janeiro. [cited 2019 jun. 7]. Available from: <http://floradobrasil.jbrj.gov.br/jabot/floradobrasil/FB83154>.

Moura MSB, Galvíncio JD, Brito LTL, Souza LSB, Sá IIS, Silva, TGF. Clima e água de chuva no semi-árido. In: Brito LTL, Moura MSB, Gama GFB, editor. Potencialidades de água de chuva no semi-árido brasileiro. Petrolina-PE: Embrapa Semi-Árido; 2007.
Nascimento HHC, Nogueira RJMC, Silva EC, Silva MA. Análise do crescimento de mudas de jatobá (Hymenaea courbaril L.) em diferentes níveis de água no sol. Revista Árvore 2011; 35 (3): 617-626.

Oliveira RA, Daros E, Zambon JLC, Weber H, Ido OT, BespalhokFilho JC, Zuffellato-Ribas KC, Silva DKT. Área foliar em três cultivares de cana-de-açúcar e sua correlação com a produção de biomassa. Pesquisa Agropecuária Tropical 2007; 37 (2), 71-76.

Pereira PC, Silva TGF, Zolnier S, Morais JEF, Santos DC. Morfogênese da Palma forrageira irrigada por gotejamento. Revista Caatinga 2015; 28 (3): 185-195.

Pimentel, C. A relação da planta com a água. Rio de Janeiro: Edur; 2004.

Plénet D, Mollier A, Pellerin S. Growth analysis of maize field crops under phosphorus deficiency. II. Radiation-use efficiency, biomass accumulation and yield components. Pant Soil 2000; 224 (2): 259-272.

Queiroz, MG, Silva, TGF, Zolnier S, Souza CAA, Souza LSB, Steidle Neto AJ, Araújo GGL, Ferreira WPM. Seasonal patterns of deposition litterfall in a seasonal dry tropical forest. Agricultural and Forest Meteorology 2019; 279: 107712.

Santiago, AMP. Nogueira RJMC. Lopes EC. Crescimento em plantas jovens de Mimosa caesalpiniifolia BENTH., cultivadas sob estresse hídrico. Revista Ecossistema 2001; 26 (1): 23-30.

Santos EM, Melo Júnior M, Silva-Cavalcanti JS, Almeida GVL. Parque Estadual Mata da Pimenteira: Riqueza Natural e Conservação da Caatinga. Recife: EDUFRPE, 2013.

Silva EC, Nogueira RJMC, Azevedo neto AD, Brito JZ, Cabral EL. Aspectos ecofisiológicos de dez espécies em uma área de caatinga no município de Cabaceiras. Iheringia Série Botânica 2004; 59 (2): 201-205.

Silva, J. M. C.; Leal, I. R.; Tabarelli, M. Caatinga: The Largest Tropical Dry Forest Region in South America. Springer, 2017. https://doi.org/10.1007/978-3-319-68339-3

Silva TGF, Moura MSB, Zolnier S, Soares JM, Vieira VJS, Gomes Júnior WF. Demanda hídrica e eficiência do uso da água da canade-açúcar irrigada no semiárido brasileiro. Revista Brasileira de Engenharia Agrícola e Ambiental 2011; 15 (12): 1257-1265.

Silva TGF, Moura MSB, Zolnier S, Souza LSB, Camo JFA. Índices morfofisiológicos e uso da radiação solar por um cultivo de canade-açúcar irrigada no Semiárido Brasileiro. Revista Brasileira de Geografia Física 2014; 7 (4): 764-773.

Souza LSB. Análise sazonal dos fluxos de carbono, energia e vapor d'água em um ecossistema de Caatinga durante um ano seco em Petrolina - PE [Tese]. Viçosa: Meteorologia Agrícola, Universidade Federal de Viçosa, Viçosa; 2014.

Souza LSB, Moura MSB, Sediyama GC, Silva TGF. Balanço de radiação em ecossistema de Caatinga preservada durante um ano seco no Semiárido Pernambucano. Revista Brasileira de Geografia Física 2015; 8 (1): 41-55.

Teixeira GCS, Stone LF, Heinemann AB. Eficiência do uso da radiação solar e índices morfofisiológicos em cultivares de feijoeiro. Pesquisa Agropecuária Tropical 2015; 45 (1): 9-17.

Trovão DMBM, Fernandes PD, Andrade LA, Dantas Neto J. Variações sazonais de aspectos fisiológicos de espécies da Caatinga. Campina Grande: Revista Brasileira de Engenharia Agrícola e Ambiental 2007; 11 (3): 307-311. 